\title{
Development of Assistive Media for Passing Volleyball for FIK UNIMED Students
}

\author{
Agung Achmadi Lumban Tobing ${ }^{1}$, Sanusi Hasibuan², M. Irfan ${ }^{3}$, Indrakasih ${ }^{4}$ \\ ${ }_{1,2,3,4}$ Sports Education, Universitas Negeri Medan, Indonesia \\ agungtobing19@gmail.com
}

\begin{abstract}
The main objective of this research is developing a medium for assisting passing over as a volleyball learning media. This research was conducted at FIK State University of Medan in 2021. Research at FIK UNIMED Medan will be carried out from February 9 to March 4, 2021. The type of research used is research and development, a small trial sample of 6 students and a large trial of 10 students as well as media, sports and language experts. In small group trialsvalidated by 3 experts, where the percentage of validity reaches $82 \%$ - $94.11 \%$ with valid criteria can be used. In large group trials the percentage of validity reaches $90 \%$ - 98.88\%with valid criteria can be used.The small group trial sample of 6 PKO FIK UNIMED students reached $80 \%$ with valid criteria, and the large group trial sample of $10 \mathrm{PKO}$ FIK UNIMED students reached $88 \%$ with valid criteria. From the test of the effectiveness and efficiency of the passing over aids with learning media experts, it reached $98.18 \%$ with valid criteria for use and sports experts reached $96.36 \%$ with valid criteria for use. On the basis of the data obtained, the development of the passingover aids media product is deemed feasible to be developed as one of the learning media aids in volleyball game material.
\end{abstract}

Keywords

volleyball; assistive

devices, learning

media

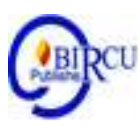

\section{Introduction}

The Faculty of Sports Science (FIK) at Medan State University is one of the faculties that specializes in sports science with a study program structure, namely: Physical Education, Health and Recreation Studies Program (Accreditation A), Sports Coaching Study Program (Accreditation A) and Study Programs Sport Science (Accreditation A). The Faculty of Sports Science (FIK) has adequate learning facilities, this faculty also has many collaborations with various institutions and institutions both government and private to support student internships and training activities.

Means are all equipment, materials, and furniture that are used directly in the teaching and learning process in schools, both moving and immovable in order to achieve educational goals so that they can run smoothly, orderly, effectively and efficiently. Educational infrastructure is all instruments that indirectly support the implementation of the educational process in educational institutions. Infrastructure means an indirect means of achieving goals in education, for example: location / place, on the school sports field, etc.

Volleyball game is a sport that aims to improve physical fitness and the development of sports achievements, therefore efforts to improve and develop volleyball learning achievements need to be practiced to improve desired performance (Ferguson, 2010). Volleyball is a sport that dominates the entire community, both students and government agencies, where the development of volleyball is very rapid, this can be seen from the 
implementation of volleyball championships at elementary, middle, high school and general level often held. (Budiarti et al, 2019)

Volleyball is one of the branches of soccer where you play it by dropping the ball on the opponent's field as much as possible to achieve a certain score. Another opinion says, the notion of volleyball is a sport that is played by two opposing groups where each group has six players. Between the two groups/teams the field is limited by a net barrier with a certain height. (Indrakasih et al, 2019).

Volleyball games have several facilities and infrastructure that can support these sports activities, such as balls, fields, shoes, clothes, poles and nets. Volleyball is a game where the dominant hand is touched only once. Volleyball requires excellent brain skills, especially setters. Setter must be able to control the course of the game. The setter needs to be able to decide what to do with the ball he gets, to provide a good pass to the spiker, and all of that is done in the fraction of a second before the ball falls onto the court throughout play. This shows that the upper pass plays a very important role in volleyball. All techniques in volleyball are used in matches including serve, passing, smash and block. The accuracy of passing over will be very supportive in giving points, because after being given a pass, the ball will smash. This proves that passing over is really important in playing volleyball in order to achieve the goals of the volleyball game.

The results of observations in the volleyball subject show that the accuracy in passing over to the target is a problem in learning. The researcher discussed with the lecturer's assistant, and the results of the conversation could be said that during the learning process, there were obstacles that could not be found a solution to be able to help effective learning. Related to this obstacle is the lack of media aids that can support learning in improving the accuracy of passing over. So far, learning has been carried out in several ways, such as passing with peers, passing by bouncing the ball itself and the current learning media used only uses wall reflections.

Based on the results of observations, the researcher designed a tool that makes it easier for students to place the ball on a volleyball target that is more feasible and effective. This tool is expected so that students can easily improve the accuracy or accuracy of passing over in volleyball learning. The needs analysis that was distributed to students also made it clear that many students stated that they needed passing-over aids to improve the accuracy or accuracy in learning volleyball material.

\section{Research Methods}

This type of research is development research or Research \& Development (R \& D) from Borg \& Gall (1983: 776).In this research, it is only limited to the stage II product revision stage. The research was carried out instudents majoring in Sports Coaching Education who take advanced volleyball courses. The population in this study were 2 classes of Sports Education students taking advanced volleyball courses. Samples were chosen randomly (random).

The data obtained during the study were analyzed based on the analysis of the instrument, the analysis of the results of the validation of the volleyball learning media expert, the analysis of the results of the validation of the volleyball sports expert and the analysis of the results of the student response questionnaire. The design of the passing over aid to be developed can be seen in Figure 1. 


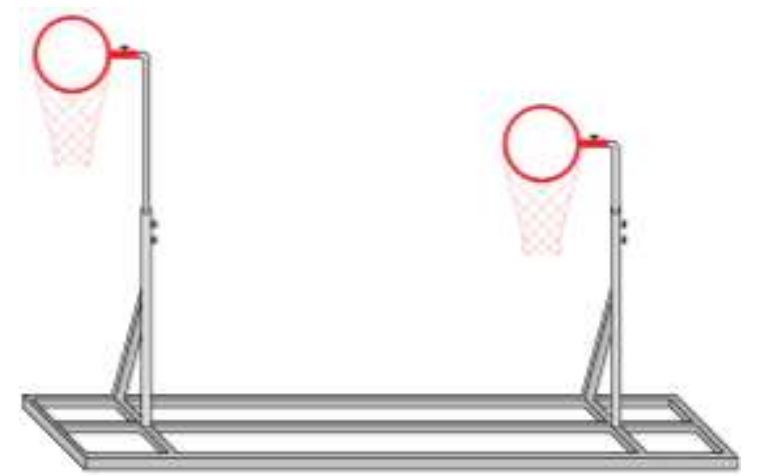

Figure 1. Tools Upper Passing Aids With Two Target Balls

\section{Results and Discussion}

This research uses this type of research development Research \& Development ( $\mathrm{R} \&$ D) from Borg \& Gall (1983: 776) which consists of eight steps. The beginning of this research phase starts from the results of the observations and provides a needs analysis that will produce data to strengthen the existing problem. The problem in the results of this observation is the absence of aids to improve the accuracy of passing over, so the researcher wants to design a tool to help students improve the accuracy of passing over in learning volleyball passing. The results of the feasibility validation analysis of the assistive media revised by media expert lecturers and volleyball sports experts with several aspects in each questionnaire, obtained a percentage value from media experts of $94.11 \%$ and the percentage value of volleyball sports experts is $87.69 \%$ with a decent category.

After the assistive media was validated and fit for use as a tool to improve the accuracy of volleyball passing in learning, a small group trial was conducted with 6 students as the subject. Small group trial analysis data was taken through the results of student respondents' questionnaires. Based on data from student respondent agke, the percentage of $80 \%$ is obtained according to the digram bars as follows:

\section{Percentage of Small Group Trials}

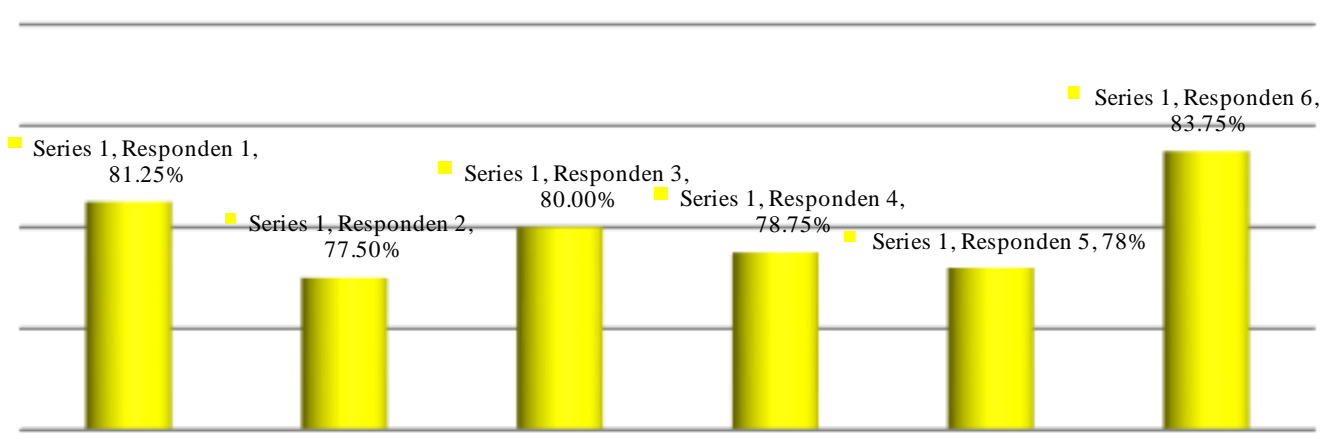


Large group trials are carried out after small group trials and receive advice from experts regarding adding several aspects to the tool. This stage is carried out with the subject of 10 students. Large group trial analysis data was taken throussgh the results of student respondents' questionnaires. Based on data from student respondent agke, the percentage of $88 \%$ is obtained according to the digram bars as follows:

\section{Percentage of Large Group Trials}

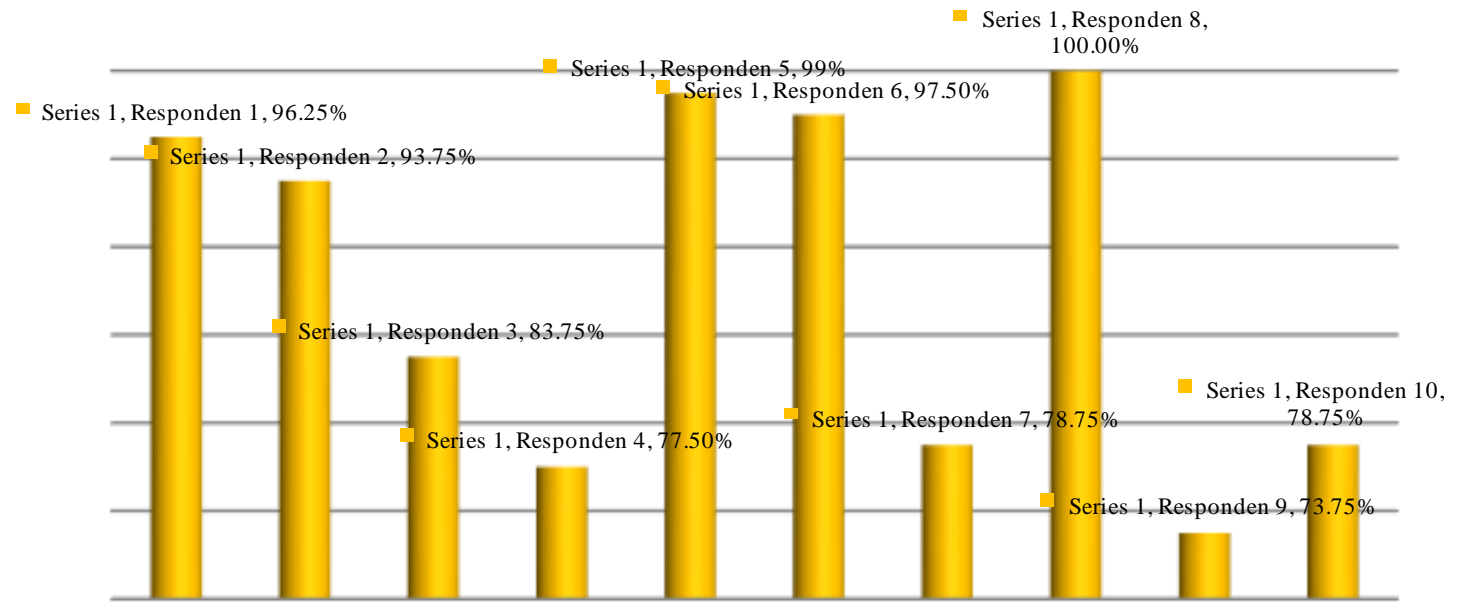

Based on the results of large group trials, the appropriateness of the tools was reassessed by instructional media experts and volleyball sports experts with several aspects in each questionnaire. The results of the feasibility validation analysis of the assistive media showed that the percentage value of media experts was $96.92 \%$ and the percentage value of volleyball sports experts was $90 \%$ with the feasible category. The end of this development research is to patent the tools and provide tools to FIK UNIMED to assist lecturers and students in developing learning using assistive tools. This top passing media can help improve the accuracy of passing over in advanced volleyball courses. The following is the final product of the research on the development of volleyball passing aid media: 


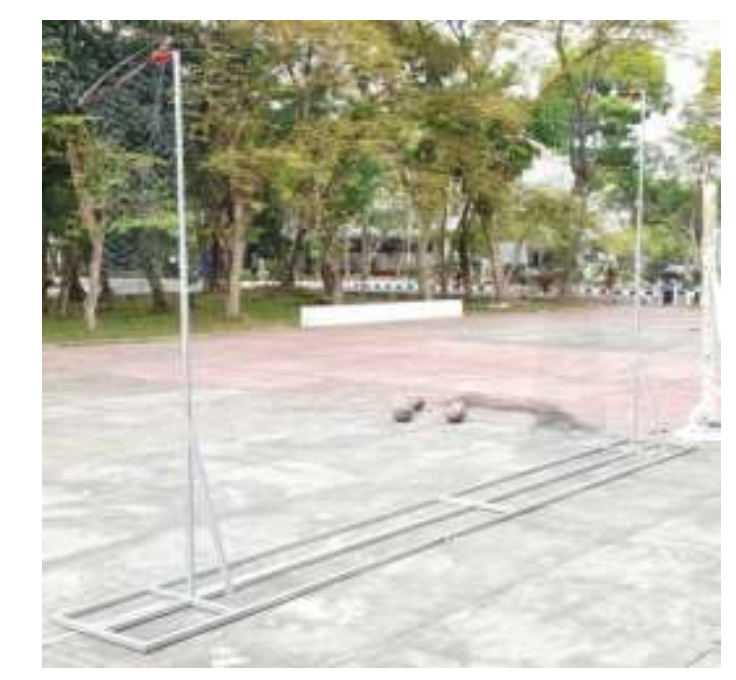

Figure 2. End Product of Top Passing Tool Media

\section{Conclusion}

Small group trials, where the value obtained is known that the score obtained is $80 \%$ (valid or feasible), it can be stated that the product of the passing-over aids media is suitable for use as learning media in volleyball courses to improve accuracy in volleyball passing techniques. Large group trials, where the value obtained is known that the score obtained is $88 \%$ (valid or feasible). This means that this research is sufficient to find out the validity of the learning aid media for volleyball passing on students of FIK Unimed. Based on data and field tests and discussion of research results, conclusions can be drawn are:

1. Produce the use of passing tools for 2 rings / targets in making it easier for students to improve their accuracy in volleyball passing techniques.

2. Producing volleyball passing aid media as a feasible and effective medium in learning volleyball passing.

\section{Suggestions and Recommendations}

Based on the existing conclusions, the suggestions put forward are as follows:

a) Volleyball passing tools can be used and help all lecturing activities of FIK students, State University of Medan, especially volleyball subjects.

b) The volleyball passing aid is easy to use and is the right solution in the learning process

c) The volleyball passing tool is a recommendation for lecturers to assist in the volleyball learning process and create creative and innovative lectures.

d) Volleyball lecturers can observe the upper passing tool (A2LT), so that they can develop more tools to be a solution to improving the learning process in volleyball subjects. 


\section{Further Development Suggestions}

For further research, the researcher provides several suggestions to do, namely

1. For research trial subjects, you should use a broader subject, such as a club or volleyball athlete.

2. The use of products, especially volleyball passing tools, can be linked to technology to make it even better.

\section{References}

Ambar Yuliana. (2015). Pengembangan Media Pembelajaran Berbasis Multimedia Flash Untuk Model Pembelajaran Kooperatif. Fakultas Teknik Universitas Negeri Semarang.

Budi Rohmad Hidayat. (2019). Survei Sarana Prasarana Dan Tenaga Pengajar Pendidikan Jasmani Olahraga Dan Kesehatan Sma Negeri Se-Kabupaten Ponorogo. FIK Universitas Negeri Surabaya. Surabaya.

Budiarti, W. et al. (2019). Volleyball Smash Learning Model for Middle School Students. P. Budapest International Research and Critics in Linguistics and Education (BirLE) Journal. P. 239-244

Dian Saputra. (2020). Manajemen Sarana Dan Prasarana Pendidikan Di Mts Yayayasan Madrasah Pendidikan Islam (Ympi) Pekon Putihdoh Kec.Cukuh Balak, Tanggamus. FTK Universitas Islam Negeri Raden Intan Lampung. Lampung.

Dwi Nugroho. (2016). Pengembangan Alat Pelontar Bola Multifungsi. (https://eprints.uny.ac.id/31686/1/SKRIPSI.pdf). Diaksestanggal 21 Januari 2016.

Fajar Hidayat. 2016. Pengembangan Multimedia Pembelajaran Pendidikan Jasmani Olahraga Dan Kesehatan Materi Budaya Hidup Sehat Untuk Siswa Sma Kelas Xi. FIK Universitas Negeri Yogyakarta. Yogyakarta.

Fajar Sriwahyuniati. (2017). Belajar Motorik. UNY Press. UNY Karangmalang Yogyakarta.

Hamdi, et al. (2020). Pengembangan Media Pembelajaran E-Learning Berbasis Moodle Pada Mata Kuliah Metodologi Penelitian. Jurnal Pendidikan Teknik Sipil. Universitas Negeri Jakarta.

Imam Dwi Saputro. (2014). Survei Sarana Dan Prasarana Pendidikan Jasmani Di Sekolah Dasar Negeri Se Kecamatan Selopampang Kabupaten Temanggung. FIK Universitas Negeri Yogyakarta. Yogyakarta.

Indrakasih, et al. (2019). Development of Basic Volleyball Learning Media Based on Web Learning Materials Towards KKNI at Universitas Negeri Medan. Budapest International Research and Critics in Linguistics and Education (BirLE)Journal. 139144.

Iwan Falahudin. (2014). Pemanfaatan Media Dalam Pembelajaran. Jurnal Lingkar Widyaiswara. Widyaiswara Balai Diklat Keagamaan (BDK). Jakarta Timur.

Jack Suman Rulis Manurung. (2020). Persepsi Mahasiswa Terhadap Kelayakan Sarana Dan Prasarana Olahraga Bola Besar. Journal of Sport Science and Physical Education. FIK STKIP Pamane Talino.

M. Rizkan Khadavi. (2020). Hubungan Sarana Prasaran Dan Motivasi Terhadap Pencapaian Prestasi Olahraga Siswa Sma Kota Pangkalpinang. Jurnal Muara Olahraga. Sekolah Tinggi Keguruan dan Ilmu Pendidikan Muhammadiyah Bangka Belitung.

Nur Afifah Sudibyo. (2019). Survei Sarana Dan Prasarana Pembelajaran Pendidikan Jasmani Olahraga Dan Kesehatan Pada Sekolah Menengah Pertama Di Kabupaten 
Pringsewu Tahun 2019. Journal of Physical Education. Universitas Teknokrat Indonesia.

PBVSI. (2020). Peraturan Resmi Bola Voli 2017-2020. pbvsi.or.id. Jakarta Selatan.

Rahmat Permana. (2020). Teori dan Praktik PENJAS di Perguruan Tinggi. Edu publisher. Jawa

Barat. https://books.google.co.id/books?hl=en\&lr=\&id=Hq_jDwAAQBAJ\&oi=fnd\&pg=PR $4 \& d q=$ pendidikan+jasmani\&ots $=X q J Z X r 5 Y Q 9 \& s i g=D k T O F u 55 B e x v \_X 0 v G O 3 H i 8$ a5dm0\&redir_esc $=\mathrm{y} \# \mathrm{v}=$ onepage $\& \mathrm{q}=$ pendidikan $\% 20 \mathrm{jasmani} \& \mathrm{f}=$ false

Ria Listina. (2012). Mengenal Olahraga Bola Voli. PT Balai Pustaka. Jakarta Timur. https://books.google.co.id/books?hl=en\&lr=\&id=qgZ9DQAAQBAJ\&oi=fnd\&pg=PP $1 \& \mathrm{dq}=$ buku+peraturan+resmi+bola+voli\&ots=D6v0m2lvWz\&sig=T6ctvcJrP7Fy1g LubvdIba6VM4w\&redir_esc=y\#v=onepage\&q=buku\%20peraturan\%20resmi\%20bol a\%20voli\&f=false

Rohani. (2019). Media Pembelajaran. Universitas Islam Negeri Sumatera Utara. Medan.

Syahrial Bakhtiar. (2015). Merancang Pembelajaran Gerak Dasar Anak. UNP PRESS. Padang

Winarno. (1995). Belajar Motorik. FIK Institut Keguruan dan Ilmu Pendidikan Malang. Malang.

Winarno.(2006). Dimensi Pembelajaran Pendidikan Jasmani Dan Olahraga. Laboratorium FIK Universitas Negeri Malang. Malang.

Winarno. (2006). Perspektif Pendidikan Jasmani Dan Olahraga. Laboratorium FIK Universitas Negeri Malang. Malang.

Winarno. (2014). Evaluasi Hasil Belajar Pendidikan Jasmani Dan Olahraga. Laboratorium FIK Universitas Negeri Malang. Malang.

Winarno.(2013). Teknik Dasar Bermain Bola Voli. Laboratorium FIK Universitas Negeri Malang. Malang.

Yanuar Kiram. (2016). Belajar Keterampilan Motorik. FIK Universitas Negeri Padang. Padang 